\title{
Test laboratory studies of refractory gold- bearing ores of Magadan Region from the standpoint of their processing by heap leaching
}

\author{
Yury Rubtsov ${ }^{1}$, Aleksandr Lavrov ${ }^{1 *}$, Aleksandr Petukhov ${ }^{1}$, Mikhail Kostromin ${ }^{1}$ and \\ Aleksandra Lavrik ${ }^{2 \dagger}$ \\ ${ }^{1}$ Transbaikal State University, 30 Aleksandro-Zavodskaya Str., Chita city, Russia, 672039 \\ ${ }^{2}$ Mining Institute FEB RAS, 51 Turgenev st., Khabarovsk, 680000, Russia
}

\begin{abstract}
The main prospects for the development of gold mining in the Kolyma area are associated with the development of ore deposits. In the southwestern part of the Tenkinsk District and in Susuman District, there are gold deposits (Pavlik, Natalka and Degdekan), which belong to the low-sulfide formation. There are some areas of poor oxidized and lowsulphide ores, the concentration of which by gravity and flotation methods becomes ineffective. At present, at the level of laboratory research and experimental field tests, some low-cost technologies for rapid and activated heap leaching of gold from poor oxidized and low sulfide ores have been developed, and they are capable to be implemented in the harsh conditions of Magadan Region. This paper describes laboratory tests of 2 types of ores from deposits in the northeastern part of Magadan Region, carried out to develop an effective cyanide technology for gold heap leaching. The studies were carried out in the laboratory of the Insitute of Mining of FarEastern Branch of the Russian Academy of Sciences and Transbaikal State University. Keywords: poor gold-bearing ores, encapsulated gold, visible and dispersed gold, mineralogical analysis, geotechnological testing, heap leaching, crushing, pelletizing, cyanide leaching of gold, photoelectric activation of solutions, acidification of solutions.
\end{abstract}

\section{Introduction}

Currently, a wealth of experience has been accumulated in the geotechnological substantiation of gold heap leaching from ore material [1-10]. Nevertheless, each goldbearing ore is characterized by its own specifics, which determine the specificity of the related geotechnologies for extracting gold from it. Magadan gold-bearing ores of lowsulphide formation are no exception, their peculiarity lies in the fact that for a number of reasons they are resistant to gold leaching. Test studies were carried out with 2 ore samples, conditionally indexed as 1 and 2. Both subtypes of this sample are mainly represented by the clay-sand fraction and debris. All mineralized rocks of the sample are characterized by dispersed dusty dissemination of sulfides (up to $1-2 \%$ of the ore mass): pyrite, rarely

\footnotetext{
*Corrsponding author: Lavrov_2002@mail.ru

† Corrsponding author: alexalavrikxx@gmail.com
} 
arsenopyrite, chalcopyrite, sphalerite, galena, and pyrrhotite. Pyrite predominates. Up to about $1 / 3$ of volume of ore sample 1 is oxidized: films, crusts and ocher of yellow-brown, brown, cherry to black color of iron oxides and hydroxides in the form of limonite, jarosite, goethite, lepidocrocite, hematite are actively developing. Thus, sample 1 can be considered not oxidized, but a transitional ore, more precisely, an ore of the oxidation zone with residual sulfide mineralization.

\section{Methodology}

Electron microscopic studies identify single grains of gold and electrum with an average size of up to 25 microns. Taking into account the ratio of the total gold and visualized gold established by the analysis, the development of ocher fixing residual gold and potentially sorbing and depositing gold released during hypergenesis with oxidation of pyrite and arsenopyrite, which are the primary gold concentrators, it can be concluded that the dispersed form of its occurrence in sample 1 is predominant. According to the results of chemical analysis, the gold content in sample 1 is $0.9 \mathrm{~g} / \mathrm{t} \div 1.09 \mathrm{~g} / \mathrm{t}$.

The quantitative assessment of the content of total, organic and inorganic carbon, carried out using a TOC-V SHIMADZU analyzer, showed that it is insignificant in the sample $\left(\mathrm{C}_{\text {total }}-0.43 \%\right.$; $\left.\mathrm{C}_{\text {inorg }}-0.27 \%, \mathrm{C}_{\text {org }}-0.16 \%\right)$.

According to the results of a chemical analysis, the total gold content in the sample ranges from 0.1 to $2.8 \mathrm{~g} / \mathrm{t}$, silver - from 2.92 to $9.91 \mathrm{~g} / \mathrm{t}$.

Mineralogical analysis has shown that sample 2 contains up to $0.66 \mathrm{~g} / \mathrm{t}$ of visible gold. Most of the gold in ore sample X2 is found in cryptocrystalline metasomatites-andesitedacites $(2.8 \mathrm{~g} / \mathrm{t})$ with unexpressed manifestations of chloritization, amphibolization, albitization, silicification processes at the macrolevel. Propylites can also be considered as conditional for gold. An assumption has been made about the form of gold occurrence, both encapsulated and chemically bound, dispersed. Such forms of its occurrence are associated mainly with quartz of a certain productive generation (most likely ferruginous - with oxidehydroxide ferruginous films and internal inclusions) and oxide-hydroxide accessory minerals.

A quantitative assessment of the content of total organic and inorganic carbon, carried out using the TOC-VSHIMADZU analyzer, showed that in sample 2, as well as in sample 1 , it is insignificant from the technological standpoint $\left(\mathrm{C}_{\text {total }}-0.43 \% ; \mathrm{C}_{\text {inorg }}-0.27 \%, \mathrm{C}_{\text {org }}-\right.$ $0.16 \%$ ). It should be noted that a significant portion of encapsulated and dispersed gold is associated with ultrafine quartz and chlorite. Comparative laboratory tests for agitational leaching of gold and silver from them were carried out in closed plastic containers on roller tables at $\mathrm{L}: \mathrm{S}=1: 1$. When using standard cyanide-hydroxide (cyanide-alkaline) complexes as reagents, the consumption of sodium cyanide was taken on the basis of reaching a concentration of $3 \mathrm{~g} / \mathrm{l}$ in the liquid phase (due to the high content of silver in ores). The consumption of calcium and sodium hydroxide was taken de facto based on the need for conditioning the medium by $\mathrm{pH}$ to a level of 10.5 . The agitation time was taken as equal to 5 hours.

At the stage of electroactivation preparation, the carbonate-bicarbonate solution is saturated with oxygen followed by formation of metastable peroxide complexes in it: $\mathrm{O}_{2}+2 \mathrm{H}_{2} \mathrm{O}=2 \mathrm{H}_{2} \mathrm{O}_{2}$. When interacting with a carbonate anion, such a complex forms a hydrated cluster of metastable mononadcarbonic acid: $2 \mathrm{H}_{2} \mathrm{O}_{2}+2 \mathrm{H}_{2} \mathrm{CO}_{3}=2 \mathrm{H}_{2} \mathrm{CO}_{4} * 2 \mathrm{H}_{2} \mathrm{O}$, in which active oxygen atoms initiate the dissociation of surrounding water molecules. Accordingly, such a cluster can protonate a significantly larger number of silicon-oxygen groups on the quartz surface and significantly increase the probability of the formation of silanol groups on the surface of quartz and aluminosilicate minerals. It can be expected that 
a cyanide solution prepared on the basis of such a carbonate solution has a significantly higher activity.

When calculating the recovery, the initial gold content $(\mathrm{g} / \mathrm{t})$ in sample 1 was taken as the sum of the values of the contents in the productive solution $\left(\mathrm{L}_{\mathrm{f}}\right)$ and cyanidation cakes $\left(\mathrm{S}_{\mathrm{f}}\right)$, i.e., $\mathrm{L}_{\mathrm{f}}+\mathrm{S}_{\mathrm{f}}=0.95+0.14=1.09 \mathrm{~g} / \mathrm{t}=100 \%$. When calculating the recovery of gold for sample 2 , the ratios of its content in the productive solution and in the original solid as well as the ratio of its content in the productive solution and the sum of the contents in the productive solution (liquid phase) and cyanidation cakes were taken.

Ore 2 is refractory for direct cyanidation, recovery was $61-77.6 \%$. Silver recovery was about $82 \%$.

It is important to note that the $\mathrm{pH}$ value decreased according to the scheme with carbonate treatment for the weighed portion of sample 1 from 10.5 to 8.3 , according to the cyanide-hydrocarbonate scheme for sample 1 from 10.5 to 9.3 ; for sample 2 - from 10.5 to 8.5 (in control sample for 2, to 7.8). The decrease in $\mathrm{pH}$ during cyanide leaching of gold from ore containing sulfide minerals can be explained by the oxidation of sulfide minerals in the presence of oxygen with the formation of iron hydroxides and sulfuric acid. A relative excess of protons ( $\mathrm{pH}$ below 8-8.5) leads to an increase in the likelihood of the formation of hydrocyanic acid, which causes not only the loss of cyanide complexes with fumes, but the formation of an insoluble gold complex AuCN (the equilibrium shift towards $\mathrm{Au}(\mathrm{CN})_{2}$ has been experimentally proved even in slightly acidic environment). The binding of such "excess" protons is most efficient with hydroxyl ions associated with sodium rather than calcium. Therefore, the hydroxide-cyanide (alkaline-cyanide) scheme provides a minimal decrease in $\mathrm{pH}$. At the same time, increase in $\mathrm{pH}$ by alkali relative to the optimal value (10.5) is advisable only at the first stage of leaching, since accelerated binding of protons leads to a decrease in the activity of cyanides, since the complex with gold form not $\mathrm{CN}^{-}$anions, but active radicals $\mathrm{CN}^{*}$ [8], into which cyano-anions are transformed upon protonation. As is known, when $\mathrm{pH}$ rises from 6.5 to 11.5 and higher, i.e. with a decrease in the concentration of protons, the rate of dissolution of chemically pure gold in a cyanide solution sharply decreases $[7,10]$.

Comparative laboratory tests for gold heap leaching with cyanide solutions were carried out in columns $1.5 \mathrm{~m}$ high from samples 2 . The ore was crushed to a class of $5 \mathrm{~mm}$, the weighed portion was $2.5 \mathrm{~kg}$. The samples were pelletized under the same conditions using the following: water $150 \mathrm{ml}$, lime $7 \mathrm{~g}$, cement $18 \mathrm{~g}$. The ore was pelletized in a rotating drum for 3 minutes and stayed in pipes with a diameter of $0.05 \mathrm{~m}$ for 3 days. The samples under study were irrigated with cyanide solutions once a day, and the amount of solutions introduced on the first day was $200 \mathrm{ml}$, each next day $100 \mathrm{ml}$ of sodium. In the first 7 days in both studies, solutions were prepared with $\mathrm{C}_{\mathrm{NaCN}}=3 \mathrm{~g} / \mathrm{l}$, each next day with $\mathrm{C}_{\mathrm{NaCN}}=1$ $\mathrm{g} / \mathrm{l}$. The difference in the tests was in the preparation of solutions before adding into the ore. In the first case, the cyanide solution was oxygenated to the maximum possible oxygen concentration of $-38-39 \mathrm{mg} / 1$. In the second case, a $2 \%$ sodium bicarbonate solution was first prepared, which was subjected to double activation - first, electroactivation in a nonflowing cell for 1 hour, then photoactivation by ultraviolet irradiation in the electromagnetic wavelength range of 210-230 nm for 7 minutes. After that, sodium cyanide was added and the solution was additionally acidified to a concentration of 38-39 mg/l. The research results are shown in Fig. 1-2. 


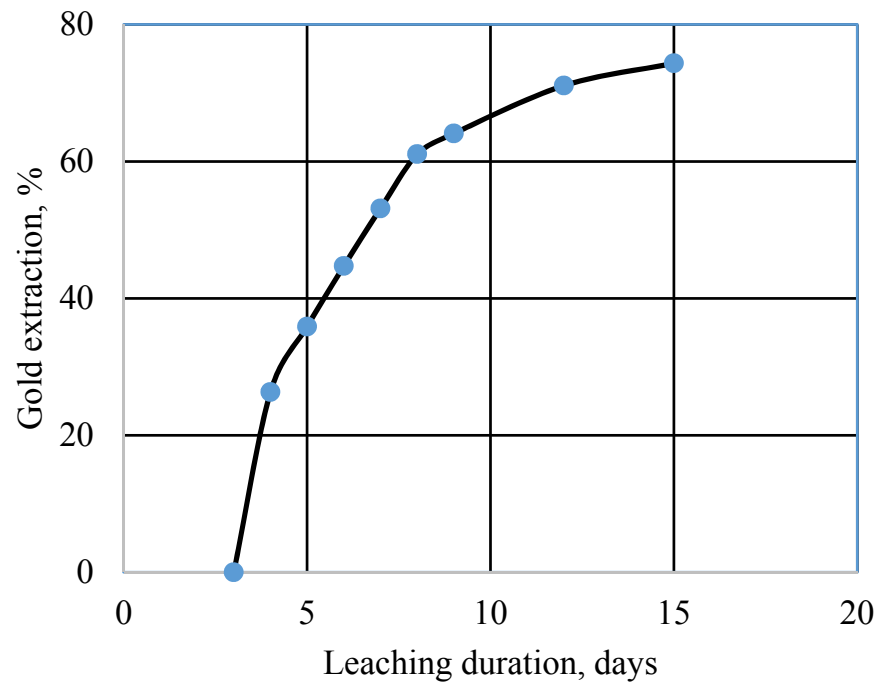

Fig. 1. Dependence of the degree of gold recovery from refractory ore sample 2 into the production solution on time in gold heap leaching test using oxygenated solutions

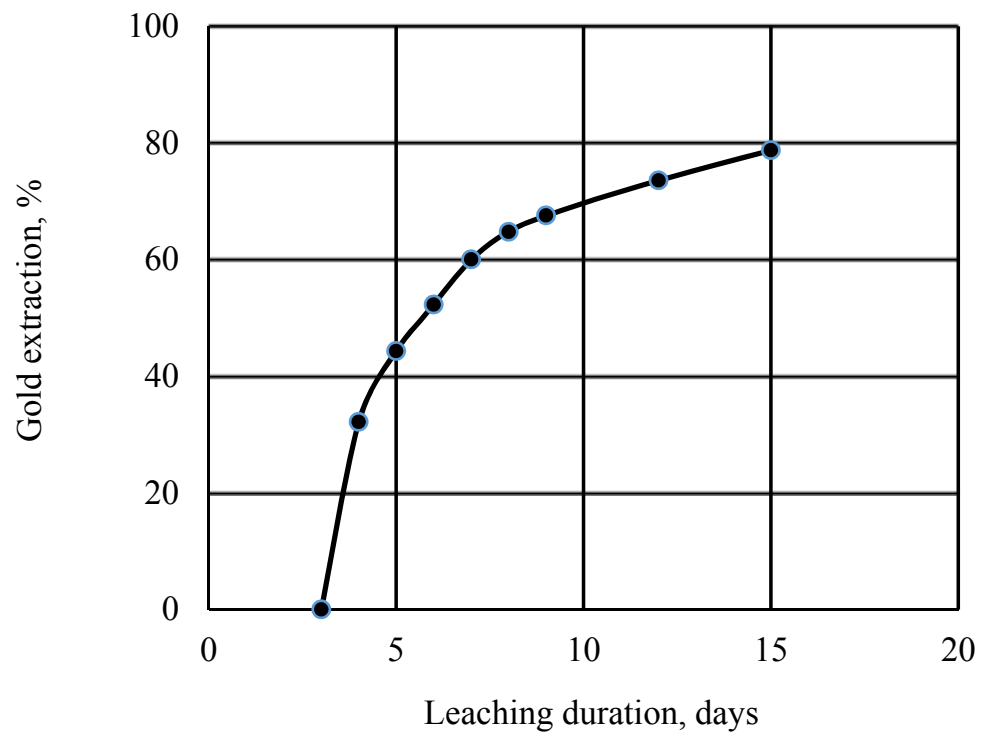

Fig. 2. Dependence of the degree of gold recovery from a refractory ore sample 2 into the production solution on time in gold heap leaching test using activated solutions.

According to the graphical data on the kinetics, one can state approximately the same results for gold recovery, which practically ends at $80 \%$ after 20 days of leaching. The duration of activation leaching in comparison with the classical gold heap leaching method from refractory gold-bearing ores is reduced several times. But, if in the test with acidification of cyanide solutions the bulk of gold was removed into the solution at gold concentrations of the order of 4-6 mg/l, then in test 2 the maximum concentration of gold in the production solutions reached more than $24 \mathrm{mg} / \mathrm{l}$. 


\section{Results and conclusions}

Agitational gold leaching tests have confirmed the likelihood of acceptable gold recovery from refractory Magadan ores using photoelectroactivated oxygenated cyanide solutions. Tests with gold heap leaching showed that the degree of gold recovery from refractory ores at the level of $75-80 \%$ using activated and oxygenated cyanide solutions under normal conditions is obtained after 15 days. The concentration of gold in the production solutions is an order of magnitude higher than in classical leaching, this implies a multiple reduction in the volume of circulating solutions and a simpler scheme for processing production solutions.

To reduce the duration of the leaching cycle and increase the effective processing of gold-resistant ores in the northeastern part of Magadan Region, it is proposed to use sodium cyanide at the stage of ore pelletizing and its subsequent storage for at least 3 days, and to use photoelectroactivated oxygenated cyanide solutions in the "piston mode" of irrigation of pelletized ore.

The developed scheme presupposes an efficient implementation of gold heap leaching from refractory ores within the short warm period of Magadan summer.

\section{References}

1. A.G. Sekisov, V.A. Khakulov, A.Yu. Budaragin, A.A. Tomskikh, A.E. Vorobiev Method for leaching dumps: US Pat. SU 1548416A1 Federal State Educational Institution of Higher Professional Education Trans-Baikal Mining College No. 2007118333/03 applied16.05.2007; published 27.03.2009.

2. G.V. Sedelnikova, Mineral resources of Russia. Economics and Management, 3, 42-45 (2001)

3. I.N. Kotlyar, Gold-silver ore content of volcano structures of the Okhotsk-Chukotka belt. (Moscow, Nauka, 1986)

4. M.V. Natalenko, Ores and metals, 3, 35-42 (2003)

5. V.P. Pokazaniev, Kolyma, 4, $42-44$ (1976)

6. L.F. Narkelyun, Geological and technological assessment of mineral raw materials. (Chita, ChitSU, 2003)

7. IN Maslenetskiy, LV. Chugaev Metallurgy of precious metals - foreign experience. (Moscow: Metallurgy, 1991)

8. A.G. Sekisov, Yu.I. Rubtsov, A.Yu. Lavrov, Zapiski gornogo instituta, 217, 96-101 (2016)

9. M.I. Fazlullin, V.I. Stupin, A.B. Belousov, A.F. Avdeev, Mining information and analytical bulletin, 5, 17-24 (2000)

10. G.Ya. Druzhina, V.E. Dementyev, G.G. Mineev, Non-ferrous metallurgy, 1, 4-9 (2004)

11. M.I. Fazlullin, A.A. Machinsky, R.N. Smirnova, V.I. Razumov, G.M. Adosik, Nonferrous metals, 8, 41-45 (2002) 